\title{
Configurações
}

\section{Introdução - Sociedade, autoridade e pós-memórias}

\section{Manuel Carlos Silva, Sheila Khan e Francisco Azevedo Mendes}

\section{(2) OpenEdition}

\section{Journals}

\section{Edição electrónica}

URL: http://journals.openedition.org/configuracoes/3083

DOI: 10.4000/configuracoes.3083

ISSN: 2182-7419

\section{Editora}

Centro de Investigação em Ciências Sociais

\section{Edição impressa}

Data de publição: 27 junho 2016

Paginação: 5-8

ISSN: 1646-5075

\section{Refêrencia eletrónica}

Manuel Carlos Silva, Sheila Khan e Francisco Azevedo Mendes, «Introdução - Sociedade, autoridade e pós-memórias », Configurações [Online], 17 | 2016, posto online no dia 30 junho 2016, consultado o 23 setembro 2020. URL : http://journals.openedition.org/configuracoes/3083 ; DOI : https://doi.org/ $10.4000 /$ configuracoes.3083 
Silva, Manuel Carlos; Khan, Sheila; Mendes, Francisco Azevedo. Sociedade, autoridade e pós-memórias. Configurações, vol. 17, 2016, pp. 5-8

\title{
Sociedade, autoridade e pós-memórias
}

\author{
MANUEL CARLOS SILVA* \\ Centro Interdisciplinar de Ciências Sociais, polo Universidade do Minho \\ SHEILA KHAN ** \\ Centro Interdisciplinar de Ciências Sociais, polo Universidade do Minho \\ FRANCISCO AZEVEDO MENDES*** \\ Lab2PT, Universidade do Minho
}

Este número sai, por coincidência, num momento significativo da vida europeia. O resultado do referendo do dia 23 de junho no Reino Unido sobre a União Europeia pode, a muitos níveis, ser lido como mais um fenómeno das encruzilhadas (pós-)memoriais, onde se jogam os sentidos das ações ditas históricas. Os horizontes onde se inscrevem estes fenómenos exigem, por isso mesmo, uma multiplicidade de questões e de tentativas de respostas sobre a matéria memorial, num exercício que deve ser encarado como interdisciplinar.

De forma incisiva, os estudos sobre a memória e a pós-memória têm recebido nas últimas décadas uma atenção significativa nas diversas áreas das ciências sociais e humanas e na criação artística. A metarreflexividade resultante dessas análises e criações, acolhendo de resto outras disciplinas, transformou decisivamente as modalidades de perceção e enquadramento dos fenómenos memoriais. A tectónica dos substratos individuais e coletivos das memórias tende, com efeito, a incorporar essas marcas metarreflexivas. Profundamente imbricadas nos mais diversos espaços e tempos e nos processos de reprodução social, memória e pós-memória, elas consubstanciam-se em vários suportes, códigos e linguagens, com mecanismos de preservação e transmissão intra e

\footnotetext{
* Investigador integrado no Centro Interdisciplinar de Ciências Sociais - Polo Universidade do Minho. Email: mcsilva2008@gmail.com.

** Investigadora no Centro Interdisciplinar de Ciências Sociais - Polo Universidade do Minho. Email: sheilakhan31@gmail.com.

*** Professor Auxiliar no Departamento de História do Instituto de Ciências Sociais e Investigador do Laboratório de Paisagens, Património e Território da Universidade do Minho e do Centro Interdisciplinar de Ciências Sociais - Polo Universidade do Minho. Email: fmendes@ics.uminho.pt.
} 
intergeracional através de diversos rituais e práticas operativas, para as quais são convocados diferentes autoridades, comunidades e/ou grupos sociais.

Neste contexto, importa problematizar os regimes de adequação entre os sujeitos que experienciam em sentido direto um evento, um momento, um fenómeno, e os sujeitos que recebem os testemunhos, que narram ou que traduzem a experiência dos outros, como uma 'segunda' memória.

Existem hierarquias entre aquele que conta, que dá o testemunho, e o destinatário pós-geracional desse testemunho, que o reescreve numa outra narrativa? Será que aquele que narra a memória dos outros tem a mesma legitimidade e autoridade na sua narrativa, quando comparada com a autoridade da narrativa original? Como medir e interpretar os intervalos críticos entre uma e outra memória? Quais as autoridades da memória e da pós-memória quando em diálogo ou confronto? Na presença dessas autoridades, quem são e onde estão os autores? Qual o valor de falarmos de uma memória multidirecional com várias escalas autorais? Será mais apropriado falar em dever de memória ou em direitos conflituais de memórias e de pós-memórias?

Os artigos apresentados neste número comprometeram-se a responder a algumas destas questões, assim como apontaram para novos caminhos.

Tendo como referente histórico os conflitos da Bósnia e do Kosovo nos anos de 1990, Jeffrew Andrew Barash debruça-se sobre a experiência histórica e a memória pública que emergiram nas últimas décadas, analisando como os avanços técnicos no domínio dos média têm simulado a experiência direta através de imagens, camuflando o fosso que separa as informações do imediato mundo da vida onde foram originadas.

Acompanhando o estudo dos discursos públicos e da memória pública, Miguel Cardina toma como base empírica um conjunto de discursos proferidos, entre 2006 e 2014, pelo então Presidente da República Portuguesa. Analisam-se as imagens do passado colonial aí presentes e de que forma elas se conectam com uma certa “memória amnésica” que reconfigura a nação.

Sheila Khan reflete sobre a maturidade dos estudos africanos no contexto português de investigação tendo em conta que em 2015 se celebraram os 40 anos de independência das ex-colónias portuguesas com todo o seu património de (pós-)memórias intelectualmente partilhadas.

O estudo de Vicente Paulino trabalha a tradição oral e o conceito de escrita na sociedade timorense, o que lhe permite problematizar com outra eficácia as condições de tradução da identidade histórica e cultural.

A importância da escrita como suporte da memória e das suas várias autoridades transparece na reflexão apresentada por Patrícia Ferreira na sua leitura crítica de A Noite das Mulheres Cantoras, de Lídia Jorge, conjugando aspetos da crítica pós-colonial e dos estudos de trauma e memória.

Sandra Sousa retoma a questão da experiência europeia em África, explorando não apenas a escrita ficcional, mas trazendo para a compreensão do 
passado colonial a importância da entrevista, outra forma de compilar, guardar memórias que nos ajudam a pensar as relações que o tempo colonial estabelecia para além dos seus limites políticos, ideológicos, concentrando-se nas missões religiosas em Angola.

Carmen Ramos Villar abre os horizontes do património e da experiência memorialística saindo do espaço europeu e africano. Nesse sentido, analisa o uso de histórias no texto memorialístico de três lusodescendentes nos EUA, mostrando como se tece a ponte de ligação entre a memória individual e a memória adquirida ou herdada.

Fabrice Schurmans regressa ao texto ficcional, à memória revelada em Beloved, de Toni Morrison, e em Húmus, de Fabienne Kanor, e que serve como reivindicação das narrativas da representação do corpo da mulher escrava, assim como da pós-memória do sofrimento decorrente do tráfico negreiro.

Os suportes audiovisuais assumem, também, um lugar de destaque pela importância que demonstram no uso do documentário, assim como da fotografia, para melhor pensar a memória.

Jessica Falconi partindo da análise do docudrama Contract de Guenny Pires aborda a história dos antigos trabalhadores cabo-verdianos que durante o colonialismo foram contratados para as plantações de cacau e café nas ilhas de São Tomé e Príncipe. A narrativa, construída a partir do relato das viagens do realizador à procura do seu tio, convoca uma reflexão em torno dos regimes de autoridade memorial instaurados pela escolha da narração em voice-over.

Elsa Peralta e Joana Oliveira recuperam pela fotografia a narrativa do retorno, após o processo de descolonização dos territórios africanos que estiveram sob a administração portuguesa, refletindo sobre o valor ético e analítico do conceito de rememoração e de arquivo.

Ana Quintais parte da noção de pós-memória para pensar criticamente as relações entre a memória, a família e a fotografia no fotógrafo e artista visual português Daniel Blaufuks, através das obras Sob Céus Estranhos e Terezín.

$\mathrm{Na}$ secção vária, apresentam-se dois artigos que incidem sobre configurações distintas do trabalho.

Manuel Carlos Silva e Rita Borges Neves apresentam uma leitura sociológica de memórias e vivências do trabalho e de desemprego em fim de carreira profissional, discutindo como as estratégias para lidar com a hetero-exclusão do mercado de trabalho podem passar pela incorporação de uma identidade deteriorada, associada a inatividade e inutilidade.

Miguel Chaves e César Morais analisam a perspetiva da inserção profissional de graduados do ensino superior, estimando e analisando o intervalo temporal entre a conclusão do curso e a obtenção de um emprego, revelando distintos tempos de inserção, tanto no acesso a um primeiro emprego, como a um emprego ajustado ao nível e à área de formação. 
Num último plano, publicam-se duas recensões. Uma, de Rui Sarapicos sobre as Vozes de Chernobyl, de Svetlana Alexievich. Outra, de Sandra Sousa que aborda a obra de Sheila Khan Portugal a lápis de cor. A sul de uma pós-colonialidade.

Pelas pistas que deixa, pelos estilos e metodologias que põe em prática, Configurações 17 constitui na nossa ótica um passo em frente, com todos os seus desafios e constrangimentos, na discussão da matéria memorial e da intrusão estranha e cada vez mais disseminada dos momentos pós-memoriais que se colam e dobram a matéria da representação das coisas e da vida. Tendo em conta a adesão suscitada, no próximo número da Configurações, na secção vária, contamos ainda publicar alguns contributos já aceites sobre esta temática. 